\title{
Oral submucous fibrosis: a contemporary narrative review with a proposed inter- professional approach for an early diagnosis and clinical management
}

Naman R. Rao ${ }^{1^{*}} \mathbb{D}$, Alessandro Villa ${ }^{2,3}$, Chandramani B. More ${ }^{4}$, Ruwan D. Jayasinghe ${ }^{5}$, Alexander Ross Kerr ${ }^{6}$ and Newell W. Johnson ${ }^{7}$

\begin{abstract}
Oral Submucous fibrosis (OSMF) has traditionally been described as "a chronic, insidious, scarring disease of the oral cavity, often with involvement of the pharynx and the upper esophagus". Millions of individuals are affected, especially in South and South East Asian countries. The main risk factor is areca nut chewing. Due to its high morbidity and high malignant transformation rate, constant efforts have been made to develop effective management. Despite this, there have been no significant improvements in prognosis for decades. This expert opinion paper updates the literature and provides a critique of diagnostic and therapeutic pitfalls common in developing countries and of deficiencies in management. An inter-professional model is proposed to avoid these pitfalls and to reduce these deficiencies.
\end{abstract}

Keywords: Oral submucous fibrosis, Global epidemiology, Areca nut, Management

\section{Introduction}

Oral Submucous Fibrosis (OSMF) is a potentially malignant disorder which was described by Schwartz in 1952 as "Atropica idiopathica mucosae oris" and later by Jens J. Pindborg in 1966 as "an insidious, chronic disease that affects any part of the oral cavity and sometimes the pharynx [1]. Although occasionally preceded by, or associated with, the formation of vesicles, it is always associated with a juxtaepithelial inflammatory reaction followed by fibroelastic change of the lamina propria and epithelial atrophy that leads to stiffness of the oral mucosa and causes trismus and an inability to eat" [1]. OSMF is also characterized by reduced movement and depapillation of the tongue, blanching and leathery texture of the oral mucosa, progressive reduction of mouth opening, and shrunken uvula [2-4]. Other terms used to describe OSMF include idiopathic scleroderma of the mouth, juxtaepithelial

\footnotetext{
* Correspondence: naman_rao@hms.harvard.edu; naman.rao0@gmail.com

${ }^{1}$ Harvard Medical School, Harvard University, Boston, MA, USA

Full list of author information is available at the end of the article
}

fibrosis, idiopathic palatal fibrosis, diffuse oral submucous fibrosis, and sclerosing stomatitis [5-8].

Epidemiology (Table 1) (Fig. 1)

Worldwide, the number of cases of OSMF was estimated to be 2.5 million in 1996 [33]. Although many case finding studies have been conducted, particularly in South and South East Asia, OSMF is not a notifiable disease and no population-based data are available [33]. The prevalence of OSMF in India has been estimated to range from $0.2-2.3 \%$ in males and $1.2-4.6 \%$ in females, with a broad age range from 11 to 60 years [34-36]. A marked increase in incidence has been observed after the widespread marketing of commercial tobacco and areca nut products, generally known as Gutkha, which is sold in single-use packets [33]. Currently, it is estimated that areca nut is consumed by $10-20 \%$ of the World's population in a wide variety of formulations [37, 38]. The global South Asian diaspora also has a significant problem with cases reported from the United Kingdom, USA, South Africa, and many European countries. 
Table 1 Worldwide prevalence studies on Oral Submucous Fibrosis

\begin{tabular}{|c|c|c|c|c|c|c|c|}
\hline Year & Authors & Study type & Sample size & Country & City/district & State/Province & Prevalence (\%) \\
\hline 1965 & Pindborg J. J. et al. [9] & Observational & 10,000 & India & Mumbai & Maharashtra & 0.50 \\
\hline 1965 & Pindborg J. J. et al. [10] & Cross sectional & 10,000 & India & Lucknow & Uttar Pradesh & 4.1 \\
\hline 1966 & Pindborg J. J. et al. [11] & Observational & 10,000 & India & Bengaluru & Karnataka & 0.18 \\
\hline 1966 & Zachariah et al. [12] & Observational & 5000 & India & Thiruvananthapuram & Kerala & 1.22 \\
\hline \multirow[t]{4}{*}{1968} & Pindborg J. J. et al. [13] & Observational & 50,915 & India & Srikakulam & Andra Pradesh & 0.04 \\
\hline & & & & & Darbhanga & Bihar & 0.07 \\
\hline & & & & & Bhavnagar & Gujarat & 0.16 \\
\hline & & & & & Ernakulum & Kerala & 0.36 \\
\hline 1970 & Wahi et al. [14] & Observational & & India & Mainpuri & Uttar Pradesh & 0.59 \\
\hline 1972 & Mehta F. S. et al. [15] & Survey & 101,761 & India & Pune & Maharashtra & 0.03 \\
\hline 1982 & Lay K. M. et al. [16] & Cross sectional & 6000 & Myanmar & Bilugyun & Mon & 0.1 \\
\hline 1988 & Seedat H. A. et al. [17] & Cross sectional & 2400 & South Africa & Durban & KwaZulu-Natal & 3.4 \\
\hline 1997 & Tang J.G. et al. [18] & Cross sectional & 11,046 & China & Xiangtan & Hunan & 3.30 \\
\hline 2006 & Patil P. B. et al. [19] & Cross sectional & 2400 & India & Dharwad & Karnataka & 7.8 \\
\hline 2007 & Hazarey V. K. et al. [20] & Cross sectional & 1000 & India & Nagpur & Maharashtra & 6.42 \\
\hline 2008 & Mathew A. L. et al. [21] & Observational & 1190 & India & Manipal & Karnataka & 2.01 \\
\hline 2008 & Mehrotra R. et al. [22] & Retrospective & 1151 & India & Allahabad & Uttar Pradesh & 17.02 \\
\hline 2012 & Sharma R. et al. [23] & Cross sectional survey & 6800 & India & Jaipur & Rajasthan & 3.39 \\
\hline 2012 & Agarwal A. et al. [24] & Observational & 750 & India & Dehradun & Uttarakhand & 5.4 \\
\hline 2013 & Bhatnagar P. et al. [25] & Survey & 8866 & India & Modinagar & Uttar Pradesh & 1.97 \\
\hline 2014 & Burungale S. U. et al. [26] & Cross sectional & 800 & India & Jaitala, Nagpur & Maharashtra & 2.62 \\
\hline 2014 & Nigam N. K. et al. [27] & Observational & 1000 & India & Moradabad & Uttar Pradesh & 6.3 \\
\hline 2015 & Patil S. et al. [28] & Observational & 5100 & India & Jodhpur & Rajasthan & 30 \\
\hline 2016 & Singh P. et al. [29] & Cross sectional survey & 132 & India & Nagpur & Maharashtra & 2.86 \\
\hline 2018 & Tyagi V. N. et al. [30] & Cross sectional & 1167 & India & Nashik & Maharashtra & 3.51 \\
\hline 2018 & Yang S. F. et al. [31] & Cross sectional & $23,373,51$ & Republic of China & - & Taiwan & 16.2 \\
\hline 2019 & More C. B, et al. [32] & Cross sectional & 13,874 & India & Vadodara & Gujarat & 7.21 \\
\hline
\end{tabular}

Table 1 and Fig. 1 present published estimates of the prevalence of OSMF, which range from 0.1 to $30 \%$, varying by geographical location, sample size, and sampling methodology. There is an urgent need for large well-designed epidemiological surveys to understand the true global and regional burden of OSMF.

\section{Major etiology, contributing factors and etiopathogenesis} (Tables 2 and 3) (Fig. 2)

Although the etiopathogenesis of this disease is multifactorial, areca nut-chewing in any formulation is considered the main causative agent. (Fig. 2) Contributory risk factors suggested includes chewing of smokeless tobacco, high intake of chilies, toxic levels of copper in foodstuffs and masticatories, vitamin deficiencies, and malnutrition resulting in low levels of serum proteins, anemia and genetic predisposition.

\section{Diagnostic approach}

Diagnosis of OSMF is based on clinical signs and symptoms that include burning sensation, pain, and ulceration (Table 4) [4, 46, 47]. Progressive restriction in mouth opening, blanching of the mucosa, depapillation of the tongue, and loss of pigmentation are other classic features (Fig. 3) [46]. Dysphonia and hearing impairment is also observed in advanced cases [48, 49]. Quality of life (QoL) is severely affected, worsening with increasing stage of the disease [50].

OSMF progresses over time and management depends on the stage at clinical presentation. In 2012, More et al. proposed a disease progression-based classification (Table 5) which represents the clinical and functional staging of OSMF. This classification has been widely accepted/ recommended as the closest fit for Indian population, especially to understand the disease progression/ clinical pattern [3, 35, 51]. In 2017, Passi D. et al. proposed a pathologically updated and treatment management-based classification. 


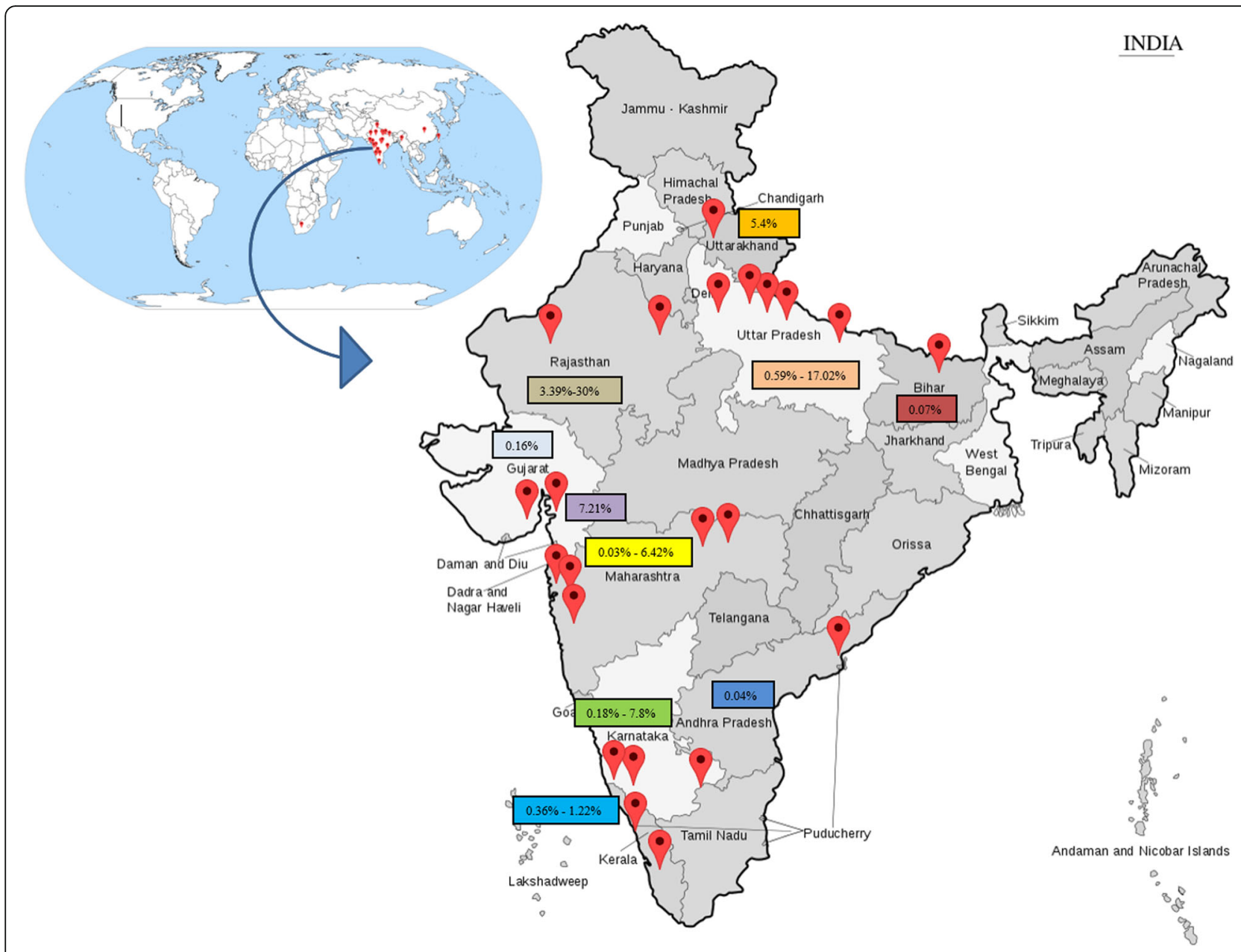

Fig. 1 Global and Indian prevalence studies of Oral Submucous Fibrosis

This classification chiefly focuses and recommends the treatment management based on the clinical stage of OSMF [52]. Later in 2018, Arakeri G. et al. proposed a threecomponent classification scheme (TFM) which can essentially be useful for effective communication amongst the care team, categorization of OSMF, recording data and disease prognosis, and treatment management. Additionally, this classification also describes OSMF malignant transformation in detail [53].

\section{Approaches to non-surgical management.}

Although there is general agreement regarding clinical staging, approaches to management of patients vary widely

Table 2 Major aetiology of Oral Submucous Fibrosis

\begin{tabular}{ll}
\hline Major aetiology & Description \\
\hline Chewing of Areca nut (Baked or Raw) & Arecoline and Arecaidine \\
and/or derivatives such as Gutkha, & nitrosation causes DNA alkylation \\
Pan masala, Mawa, Betel quid, Sweet & with proliferation of fibroblasts \\
Supari and other formulations. & and elevated collagen synthesis \\
& [39]. \\
\hline
\end{tabular}

Table 3 Contributing risk factors for Oral Submucous Fibrosis

\begin{tabular}{|c|c|}
\hline Contributing factors & Description \\
\hline $\begin{array}{l}\text { Chewing smokeless } \\
\text { tobacco }\end{array}$ & $\begin{array}{l}\text { Dip, Snuff, Snus and chewing tobacco have been } \\
\text { reported as major contributing factors [34, 35, 39, } \\
\text { 40]. }\end{array}$ \\
\hline Nutritional & $\begin{array}{l}\text { Deficiencies of iron, folate \& vitamin B12 result in } \\
\text { mucosal atrophy, notably in the mouth. Increased } \\
\text { levels of iron enhance hydroxylation of proline } \\
\text { and lysine in the process of collagen synthesis } \\
\text { [40]. }\end{array}$ \\
\hline Chilies & $\begin{array}{l}\text { Hypersensitivity reactions to capsaicin might } \\
\text { contribute to fibrosis [41-43]. }\end{array}$ \\
\hline $\begin{array}{l}\text { Toxic levels of } \\
\text { copper }\end{array}$ & $\begin{array}{l}\text { Copper upregulates the enzyme lysyl oxidase, } \\
\text { enhancing cross linking of collagen and elastin } \\
{[35,44,45] \text {. }}\end{array}$ \\
\hline $\begin{array}{l}\text { Genetic } \\
\text { predisposition }\end{array}$ & $\begin{array}{l}\text { HLA-A10, HLA-B7, HLA-DR3, haplotypes A10/DR3, } \\
\text { B3/DR3 and A10/B8 are found in increased fre- } \\
\text { quency in OSMF patients [45]. }\end{array}$ \\
\hline $\begin{array}{l}\text { Immunological } \\
\text { predisposition }\end{array}$ & $\begin{array}{l}\text { Subjects with high endogenous expression of } \\
\text { CD4 and HLA-DR on lymphocytes and Langer- } \\
\text { hans cells may have dysregulation of their } \\
\text { immune-inflammatory response with bystander } \\
\text { tissue injury [45]. }\end{array}$ \\
\hline
\end{tabular}




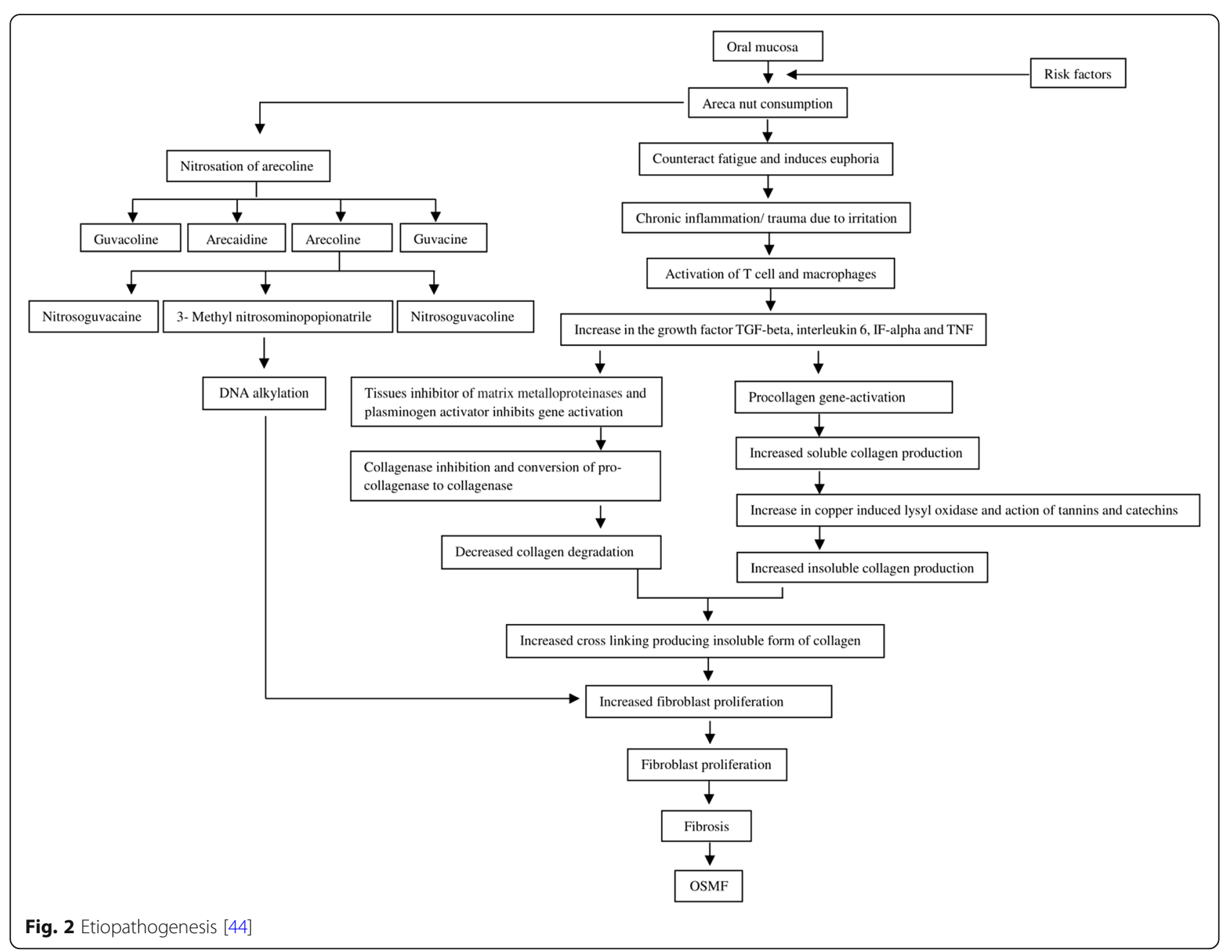

Table 4 Intra- and extra- oral manifestations of OSMF at different stages

\begin{tabular}{|c|c|c|c|}
\hline Features & Early stage & Moderate stage & Advanced stage \\
\hline $\begin{array}{l}\text { Intra } \\
\text { oral }\end{array}$ & $\begin{array}{l}\text { Stomatitis, excessive salivation, burning } \\
\text { sensation, blanching of oral mucosa, blister } \\
\text { formation, presence of thin palpable fibrous } \\
\text { bands, sparse brown/black pigmentation. }\end{array}$ & $\begin{array}{l}\text { Stomatitis, burning sensation, xerostomia, loss of } \\
\text { taste sensation, gradual decrease in mouth } \\
\text { opening, difficulty in whistling, vesicle } \\
\text { formation, petechiae, rigid oral mucosa, difficulty } \\
\text { in blowing the cheeks, defective gustatory } \\
\text { sensation, blanching of oral mucosa - especially } \\
\text { of soft palate, buccal mucosa, labial mucosa, } \\
\text { tongue, floor of mouth, and faucial pillars. } \\
\text { Presence of thick palpable fibrous bands, } \\
\text { shrunken uvula with altered shape (inverted, } \\
\text { hockey stick, bud like, deviated). }\end{array}$ & $\begin{array}{l}\text { Stomatitis, burning sensation, xerostomia, } \\
\text { reduction in mouth opening, restricted tongue } \\
\text { movement, loss of taste sensation, Unable to } \\
\text { blow the cheeks, defective gustatory sensation, } \\
\text { inability to whistle, blanching of oral mucosa: } \\
\text { esp. soft palate, buccal mucosa, labial mucosa, } \\
\text { tongue, floor of mouth, and faucial pillars. Loss } \\
\text { of suppleness of mucosa, mottled or opaque or } \\
\text { white marble like appearance of oral mucosa, } \\
\text { thick palpable fibrous bands on buccal and } \\
\text { labial mucosa, de-papillation of tongue, } \\
\text { shrunken uvula with altered shape (inverted, } \\
\text { hockey stick, bud like, deviated), involvement of } \\
\text { the pharyngeal and esophageal mucosa. }\end{array}$ \\
\hline $\begin{array}{l}\text { Extra } \\
\text { oral }\end{array}$ & No Significant extra oral features are observed. & $\begin{array}{l}\text { Prominent masseter muscle, nasal twang, } \\
\text { sunken cheeks, thinning of lips, difficulty in } \\
\text { deglutition, loss of naso-labial fold, prominent } \\
\text { antegonial notch, hoarseness of voice, mild } \\
\text { hearing impairment, weight loss. }\end{array}$ & $\begin{array}{l}\text { Hypertrophic and stiff masseter muscle, nasal } \\
\text { intonation of voice, sunken cheeks, multiple } \\
\text { folds on cheeks when attempting wide opening } \\
\text { of mouth, thinning of lips, difficulty in } \\
\text { deglutition, loss of naso-labial fold, prominent } \\
\text { antegonial notch, hoarseness of voice, severe } \\
\text { hearing impairment, severe weight loss, hoarse- } \\
\text { ness of voice, difficulty in deglutition, atrophy of } \\
\text { facial musculature. In severe cases, radiographic- } \\
\text { ally, there is alteration in condylar form and fi- } \\
\text { brous ankylosis of the temporomandibular } \\
\text { joints. }\end{array}$ \\
\hline
\end{tabular}




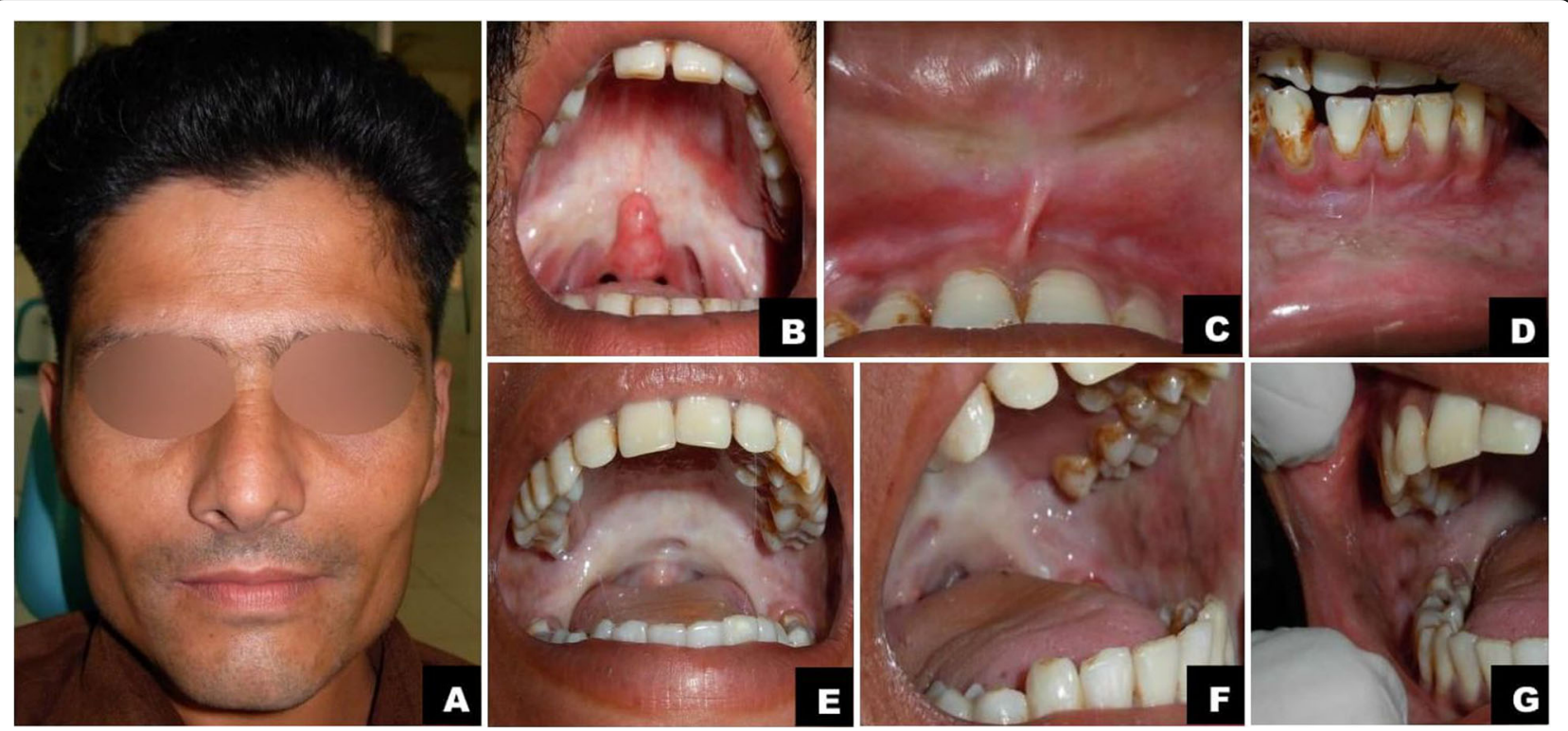

Fig. 3 Clinical expressions of Oral Submucous Fibrosis. Oral Submucous Fibrosis in a 27-year-old male with a history of gutkha chewing. Panel A shows sunken cheeks and prominent malar bone. Panel B shows significant blanching or marble-like appearance of the soft palate and faucial pillars. Note the altered, inverted shape of the uvula. Panels C \& D show blanched bands of upper and lower labial mucosae and vestibule, which are stiff and palpable. Panels E, F \& G: A 24-year-old female with a history of chewing baked areca nut. Panel E: significant blanching of soft palate and faucial pillars, and shrunken uvula. Panels F \& G: thick fibrous bands and brown/black pigmentation on left \& right buccal mucosae

[54]. Numerous interventions have been reported and are summarized in Table 6 [60, 68-70]. Supportive regimens, such as vitamin and iron supplements, a mineral-rich diet, red fruits, green leafy vegetables, and green tea consumption, are often recommended but there are no good quality studies confirming their efficacy.

Table 5 More et al. 2012 classification of OSMF

\begin{tabular}{|c|c|}
\hline $\begin{array}{l}\text { Clinical } \\
\text { staging }\end{array}$ & Interpretation \\
\hline Stage 1 (S1) & Stomatitis and/or blanching of oral mucosa. \\
\hline Stage 2 (\$2) & $\begin{array}{l}\text { Presence of palpable fibrous bands in buccal mucosa } \\
\text { and/or oropharynx, with /without stomatitis. }\end{array}$ \\
\hline Stage 3 (S3) & $\begin{array}{l}\text { Presence of palpable fibrous bands in buccal mucosa } \\
\text { and/or oropharynx, and in any other parts of oral cavity, } \\
\text { with/ without stomatitis. }\end{array}$ \\
\hline \multirow[t]{2}{*}{ Stage 4 (S4) } & $\begin{array}{l}\text { Any one of the above stages along with other } \\
\text { potentially malignant disorders (e.g. oral leukoplakia, } \\
\text { oral erythroplakia) }\end{array}$ \\
\hline & $\begin{array}{l}\text { Any one of the above stages along with oral squamous } \\
\text { cell carcinoma. }\end{array}$ \\
\hline $\begin{array}{l}\text { Functional } \\
\text { staging }\end{array}$ & Interpretation \\
\hline M1 Staging & $\begin{array}{l}\text { Interincisal mouth opening up to or greater than } 35 \\
\text { mm. }\end{array}$ \\
\hline M2 Staging & Interincisal mouth opening between 25 and $35 \mathrm{~mm}$. \\
\hline M3 Staging & Interincisal mouth opening between 15 and $25 \mathrm{~mm}$. \\
\hline M4 Staging & Interincisal mouth opening less than $15 \mathrm{~mm}$. \\
\hline
\end{tabular}

\section{Malignant transformation of OSMF}

OSMF is classified as an oral potentially malignant disorder (OPMD) [3]. Patients with OSMF have been reported with higher risk of developing oral squamous cell carcinoma (OSCC), compared to other OPMD's [71, 72]. Although 7.6\% of OSMF cases transformed to oral squamous cell carcinoma (OSCC) in a 17-year follow up study reported in 1970 [73], other studies with smaller follow up periods report malignant transformation rates ranging from 1.9-9\%, [74-76] depending on diagnostic criteria and duration of follow up [77].

Studies suggest that malignant transformation in patients with OSMF differs from those without OSMF. This difference is believed to arise from the mechanism of areca nut carcinogenesis. A retrospective study conducted in China reported that oral cancer originating from OSMF is clinically more invasive and exhibits higher metastasis and recurrence rates compared to "conventional" OSCC [78]. In contrast, Chaturvedi et al. found that OC arising in a background of OSMF represented a clinico-pathologically distinct entity, less aggressive than the "conventional" tobacco-related OC's seen in India [46]. Better prognostic features associated with OC occurring in a background of OSMF included early tumor stage, thinner lesions, fewer neck metastases with less extra-capsular spread, and more highly differentiated neoplasms. It was suggested that fibrosis in the oral mucosa and tumor stroma, with reduced vascularity, inhibits lymphatic and vascular spread [46]. 
Table 6 Treatments for OSMF

\begin{tabular}{|c|c|c|c|c|c|}
\hline $\begin{array}{l}\text { Treatment } \\
\text { type }\end{array}$ & Agent & Authors & Study Type & $\begin{array}{l}\text { Sample } \\
\text { size (n) }\end{array}$ & Main findings \\
\hline \multirow[t]{5}{*}{$\begin{array}{l}\text { Antioxidant } \\
\text { treatments }\end{array}$} & Lycopene & $\begin{array}{l}\text { Karemore T. V. } \\
\text { and Motwani M } \\
\text { [55]. }\end{array}$ & $\begin{array}{l}\text { Single blinded prospective } \\
\text { study }\end{array}$ & 92 & $\begin{array}{l}\text { Ingestion of } 8 \mathrm{~g} / \mathrm{QD} \text { of lycopene }(n=46) \text { for three } \\
\text { months was shown to be effective in the reduction of } \\
\text { burning mouth and mouth opening }(p<0.05) \text { in patients } \\
\text { with OSMF when compared to the placebo group ( } n= \\
\text { 46). }\end{array}$ \\
\hline & Curcumin & $\begin{array}{l}\text { Hazarey V. et al. } \\
\text { [56] }\end{array}$ & $\begin{array}{l}\text { Randomized control clinical } \\
\text { trial }\end{array}$ & 30 & $\begin{array}{l}\text { Sucking } 2 \mathrm{~g} / \mathrm{QD} \text { of Curcumin lozenges }(n=15) \text { with } \\
\text { physiotherapy for three months showed a significant } \\
\text { improvement in both mouth opening and in alleviating } \\
\text { the burning sensation }(p<0.05) \text { in comparison to the } \\
\text { control group (clobetasol propionate } 0.05 \% ;(n=15) \text {. }\end{array}$ \\
\hline & $\begin{array}{l}\text { Micronutrient } \\
\text { therapy }\end{array}$ & $\begin{array}{l}\text { Maher R. et al. } \\
{[57]}\end{array}$ & $\begin{array}{l}\text { Single arm preliminary } \\
\text { prospective study }\end{array}$ & 117 & $\begin{array}{l}\text { Swallowing micronutrient supplements: vitamins } A \text {, B } \\
\text { complex, } C, D, E \text {; and minerals iron, calcium, copper, zinc, } \\
\text { and magnesium was observed to be significantly } \\
\text { effective }(p<0.05) \text { in reduction of sign and symptoms of } \\
\text { OSMF over } 3 \text { years. }\end{array}$ \\
\hline & $\begin{array}{l}\text { Spirulina and } \\
\text { Aloe Vera }\end{array}$ & Patil S. et al. [58] & $\begin{array}{l}\text { Double blinded prospective } \\
\text { study }\end{array}$ & 42 & $\begin{array}{l}\text { Ingestion of } 500 \mathrm{mg} / \mathrm{QD} \text { of Spirulina }(n=21) \text { for } 3 \\
\text { months was associated with a significant improvement } \\
\text { in mouth opening and reduction in ulcers/erosions/ } \\
\text { vesicles }(p<0.05) \text { in comparison to } 5 \mathrm{mg} \text { of aloe vera } \\
(n=21) \text { for the same time. Improvement in burning } \\
\text { sensation and pain associated with lesions was not } \\
\text { found significant between two groups }\end{array}$ \\
\hline & & $\begin{array}{l}\text { Alam S. et al. } \\
\text { [59] }\end{array}$ & $\begin{array}{l}\text { Double-blinded, placebo- } \\
\text { controlled, parallel-group ran- } \\
\text { domized controlled trial }\end{array}$ & 60 & $\begin{array}{l}\text { Application of aloe vera gel over buccal mucosa, palate, } \\
\text { retromolar region, and floor of the mouth twice daily } \\
\text { during submucosal injection of hyaluronidase and } \\
\text { dexamethasone ( } n=15) \text { and surgical treatment (buccal } \\
\text { fat pad, nasolabial flap, or collagen membrane, }(n=15) \\
\text { treatment with } 6 \text { months of follow up was observed to } \\
\text { be a significant adjuvant therapy in reduction of most of } \\
\text { the symptoms of OSMF ( } p<0.01) \text {, in comparison to a } \\
\text { similar group of medicines alone, }(n=15) \text { and surgical } \\
\text { procedures ( } n=15) \text { ] with no application of aloe vera. }\end{array}$ \\
\hline
\end{tabular}

\begin{tabular}{|c|c|c|}
\hline $\begin{array}{l}\text { Medicinal } \\
\text { treatments }\end{array}$ & Steroids & $\begin{array}{l}\text { Goel S. et al. } \\
\text { [60] }\end{array}$ \\
\hline
\end{tabular}

Hyaluronidase James L. et al. Retrospective study [61] $\begin{array}{lll}\text { Colchicine }+ & \text { Krishnamoorthy } & \text { Comparative prospective } \\ \text { Hyaluronidase } & \text { B. \& Khan M } & \text { study }\end{array}$ [62].

Placental Singh P. et al. extracts
Comparative prospective study

$4 \mathrm{mg} / \mathrm{ml} /$ biweekly injections of Betamethasone diluted in $1.0 \mathrm{ml}$ of $2 \%$ xylocaine for 6 months given on buccal mucosa, bilaterally, using an insulin syringe, with a half dose on each side, was showed significant improvement of mouth opening and reduction in burning sensation in a stage II and stage III OSMF group ( $p<0.0001)$, in comparison to a control group which received no treatment over two years.

Intralesional injection of Hyaluronidase $1500 \mathrm{IU}$ mixed in $1.5 \mathrm{ml}$ of dexamethasone and $0.5 \mathrm{ml}$ of lignocaine hydrochloride biweekly for 4 weeks showed a significant improvement in mouth opening with net gain of $6 \pm 2$ $\mathrm{mm}(92 \%)$, reducing the burning sensation (89\%), number of painful ulceration (78\%) and blanching of oral mucosa (71\%) for Grade III OSMF patients.

$1 \mathrm{mg} /$ day colchicine tablet and $0.5 \mathrm{ml}$ intralesional Injection hyaluronidase $1500 \mathrm{IU} /$ once a week (group I, $n=25$ ) for twelve weeks showed a significant improvement in mouth opening $(p<0.05)$ and reduced burning sensation (33\% by second week) in comparison to subjects treated with $0.5 \mathrm{ml}$ intralesional injection of hyaluronidase $1500 \mathrm{IU}$ and $0.5 \mathrm{ml}$ intralesional injection hydrocortisone acetate $25 \mathrm{mg} / \mathrm{ml}$ once a week alternatively (group $\|, n=25$ ).

$2 \mathrm{ml}$ intralesional placental extract mixed with $2 \mathrm{ml}$ of $2 \%$ lignocaine HCL weekly for an interval of 8 weeks showed an average improvement in mouth opening by $8.02 \mathrm{~mm}$ (average pretreatment mouth opening $=18.49 \mathrm{~mm}$, average posttreatment mouth opening $=26.51 \mathrm{~mm}$ ) with average marked reduction in burning sensation by 4.9 (average pretreatment burning sensation $=8.0$, average 
Table 6 Treatments for OSMF (Continued)

\begin{tabular}{|c|c|c|c|c|c|}
\hline $\begin{array}{l}\text { Treatment } \\
\text { type }\end{array}$ & Agent & Authors & Study Type & $\begin{array}{l}\text { Sample } \\
\text { size (n) }\end{array}$ & Main findings \\
\hline & & & & & $\begin{array}{l}\text { posttreatment burning sensation }=3.1) \text {. Burning } \\
\text { sensation was assessed using visual analogue scale with } \\
0-10 \text {, where } 0=\text { no burning sensation and } 10= \\
\text { maximum burning sensation. }\end{array}$ \\
\hline & Isoxupurine & $\begin{array}{l}\text { Bhadage C. J. } \\
\text { et al. [64] }\end{array}$ & Prospective study & 40 & $\begin{array}{l}10 \text { mg Isoxsuprine tablets/ QID with oral physiotherapy } \\
\text { (Group } A, n=15 \text { ) plus } 2 \mathrm{ml} \text { dexamethasone by } \\
\text { intralesional injection with } 1500 \text { IU hyaluronidase mixed } \\
\text { with } 1 \mathrm{ml} \text { of } 2 \% \text { lignocaine solution with adrenaline } 1: 80 \text {, } \\
000 \text { (Group } B, n=15) \text { for six weeks with a follow up of } 4 \\
\text { months, showed a significant improvement in mouth } \\
\text { opening ( }(p<0.05 \text { ) and burning sensation }(p<0.00001 \text { ) in } \\
\text { comparison to the placebo group (only oral } \\
\text { physiotherapy) (Group } C, n=10 \text { ). }\end{array}$ \\
\hline & Pentoxifylline & $\begin{array}{l}\text { Rajendran R. } \\
\text { et al. [65] }\end{array}$ & $\begin{array}{l}\text { Randomized controlled } \\
\text { clinical trial }\end{array}$ & 29 & $\begin{array}{l}400 \mathrm{mg} / \text { TID of Pentoxifylline tablets ( } n=14) \text { for seven } \\
\text { months showed a significant improvement in mouth } \\
\text { opening }(p<0.0001) \text {, tongue protrusion }(p<0.05) \text {, relief } \\
\text { from perioral fibrotic bands }(p<0.0001) \text {, subjective } \\
\text { symptoms of intolerance to spices }(p<0.0001) \text {, burning } \\
\text { sensation of mouth ( } p<0.0001) \text {, tinnitus }(p<0.0001 \text { ), } \\
\text { difficulty in swallowing }(p<0.0001) \text { and difficulty in } \\
\text { speech ( } p<0.0001) \text { in comparison to the control group } \\
\text { (multivitamin with local heat therapy, } n=15) \text {. }\end{array}$ \\
\hline $\begin{array}{l}\text { Oral } \\
\text { physiotherapy }\end{array}$ & $\begin{array}{l}\text { Ultrasound }+ \\
\text { Physiotherapy }\end{array}$ & $\begin{array}{l}\text { Kumar V. et al. } \\
{[66]}\end{array}$ & Single arm prospective study & 15 & $\begin{array}{l}\text { Ultrasound therapy with } 0.7-1.5 \mathrm{~W} / \mathrm{Cm}^{2} \text { with thumb } \\
\text { kneading physiotherapy for six days/ week for two } \\
\text { consecutive weeks showed significant improvement in } \\
\text { mouth opening }(p<0.001) \text { and reduction of burning } \\
\text { sensation. }\end{array}$ \\
\hline $\begin{array}{l}\text { Surgical } \\
\text { approaches }\end{array}$ & Surgery & $\begin{array}{l}\text { Kamath V. V } \\
\text { [67]. }\end{array}$ & Systematic Review & - & $\begin{array}{l}\text { Lasers, tongue flap, palatal flap, buccal fat pad, nasolabial } \\
\text { flap, thigh flaps, split skin grafts, collagen membrane, } \\
\text { artificial dermis, human placenta grafts, } \\
\text { coronoidectomies, muscle myotomies and oral stents. All } \\
\text { surgeries have shown significant improvement in the } \\
\text { symptoms of OSMF. However there exist no definite } \\
\text { protocols and thus author comments that treatment } \\
\text { remains subjective to the operating surgeon. }\end{array}$ \\
\hline
\end{tabular}

Studies have shown higher risk of malignant transformation of OSMF when observed with simultaneous oral leukoplakia [77]. A wide array of studies was implemented recently to determine the possible mechanisms involved in malignant transformation, and many have focused their attention on molecular markers which could be helpful for early diagnosis and have possible, helpful therapeutic implications [79-81].

\section{Proposed diagnostic and management approach}

As with other lifestyle related diseases, primary prevention at population and individual levels needs to be improved. Space does not permit an exhaustive discussion of the approaches here but, in the case of OSMF, this involves education of the public regarding the dangers of areca nut and tobacco, and legislation to restrict the sale of gutkha and similar products [82-84]. Several Indian states have had success in this regard. Since May 2013, gutkha is banned in 24 states and 5 union territories of India, under the provision of centrally enacted Food Safety and Regulation (Prohibition) Act 2011 [85]. The ban is enforced by the State public health ministry, Food and Drug Administration and the local police. Although there is a significant reduction in the legal purchase of gutkha, the Supreme Court and higher enforcement bodies are still chasing to cease the illegal sale $[85,86]$.

What of the many millions already afflicted? Despite efforts to improve the management of OSMF, many come so late to diagnosis that cure is impossible, and interventions are of limited efficacy. So early diagnosis is of great importance. Further, most OSMF patients chew tobacco as well as an areca nut product, may imbibe unhealthy amounts of alcohol, and abuse other drugs. They often have dietary deficiencies. Therefore, they are at high risk of co-morbidities, including metabolic syndromes, respiratory, gastrointestinal/liver and cardiovascular diseases. (Fig. 4) [87, 88].

Dependent on their dominant symptoms, patients may seek consultation from either primary care physicians (PCP) or dentists. When examined by a dentist, the diagnostic and treatment approach is likely to be focused on the oral signs and symptoms. Conversely, 


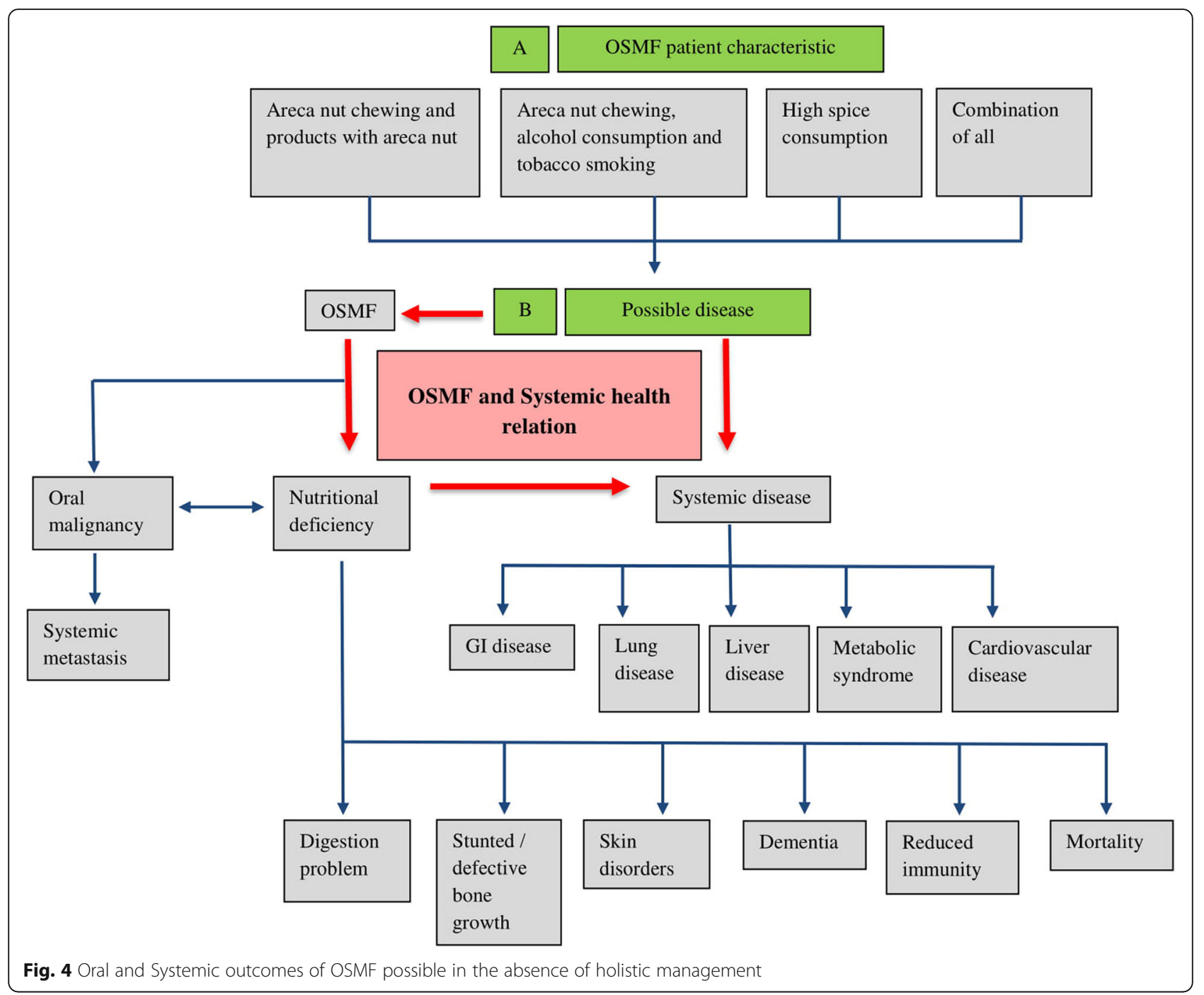

when patients present to a $\mathrm{PCP}$, the focus of management is likely to be general, with the oral condition under-investigated and under-managed. In most of the world, these patients are not managed by a multidisciplinary team.

We propose an inter-professional approach that may increase rates of early diagnosis of OSMF and potentially malignant disorders/OSCC, with integrated management of both oral and systemic symptoms, improving longterm prognosis, reducing suffering and improving quality of life.

When a patient presents to a dentist, and a clinical diagnosis of OSMF is made, he/she should be referred to their primary care physician with a note of planned dental management. If any underlying systemic disease is diagnosed, the medical treatment plan should be communicated back to the dentist. If no systemic disease is diagnosed, a written medical clearance letter, including an assessment of risks of developing any systemic condition, and recommendations for review visits, should be included.

When a patient presents to a physician, if he/she is a user of areca nut, and especially if restricted mouth opening is present, he/she should be immediately referred to a dentist detailing any planned management of other disease. The dentist should report back to the physician with a treatment plan for OSMF, if present, or dental clearance letter with a suggested risk of developing OSMF or any other oral disease.

This, after all, should be routine in any integrated health care system.

\section{Conclusion}

Although studied intensively over many decades, one might say centuries, especially in South Asia, OSMF is hardly recognized and is poorly understood across the globe. The incidence is rising; there has been no 
significant improvement in management, nor reduction in its high malignant transformation rate.

Better integration of medical and dental services, especially in developing countries, may reduce patients' suffering and improve their life quality. All health care professions must work together in public education and primary prevention.

\section{Acknowledgements}

Not applicable.

\section{Authors' contributions}

This manuscript arises out of discussions between the authors, both at international scientific meetings and in private. All have considerable experience of treating and researching Oral Submucous Fibrosis and similar disorders. The first draft was written by Naman Rao and revised with input from all other authors. All authors have approved the final version.

\section{Funding}

Not applicable.

\section{Availability of data and materials}

Not applicable.

\section{Ethics approval and consent to participate}

Not applicable.

\section{Consent for publication}

The clinical photographs shown are from Department of Oral Medicine and Maxillofacial Radiology, K. M. Shah Dental College and Hospital, Sumandeep Vidyapeeth University, Vadodara, Gujarat state, India. The consent for publishing the photograph was taken from the patients.

\section{Competing interests}

The authors declare that they have no competing interests.

\begin{abstract}
Author details
${ }^{1}$ Harvard Medical School, Harvard University, Boston, MA, USA. ${ }^{2}$ Division of Oral Medicine and Dentistry, Brigham and Women's Hospital, Boston, MA USA. ${ }^{3}$ Harvard School of Dental Medicine, Boston, MA, USA. ${ }^{4}$ Department of Oral Medicine and Radiology, K. M. Shah Dental College and Hospital, Sumandeep Vidyapeeth University, Vadodara, Gujarat, India. ${ }^{5}$ Department of Oral Medicine and Periodontology, Faculty of Dental Sciences, University of Peradeniya, Peradeniya, Sri Lanka. ${ }^{6}$ Department of Oral and Maxillofacial Pathology, Radiology and Medicine, NYU College of Dentistry, New York, NY, USA. ${ }^{7}$ Menzies Health Institute Queensland, Griffith University, Southport, Queensland, Australia.
\end{abstract}

Received: 7 August 2019 Accepted: 1 January 2020

Published online: 08 January 2020

\section{References}

1. Pindborg JJ, Sirsat SM. Oral submucous fibrosis. Oral Surg Oral Med Oral Pathol. 1966;22(6):764-79.

2. Ahmad MS, Ali SA, Ali AS, Chaubey KK. Epidemiological and etiological study of oral submucous fibrosis among gutkha chewers of Patna, Bihar India. J Indian Soc Pedod Prev Dent. 2006;24(2):84-9.

3. More CB, Das S, Patel H, Adalja C, Kamatchi V, Venkatesh R. Proposed clinical classification for oral submucous fibrosis. Oral Oncol. 2012;48(3):200-2.

4. More $C B$, Rao NR. Proposed clinical definition for oral submucous fibrosis. J Oral Biol Craniofac Res. 2019;9(4):311-4.

5. Aziz SR. Coming to America: betel nut and oral submucous fibrosis. J Am Dent Assoc. 2010;141(4):423-8.

6. Kerr AR, Warnakulasuriya S, Mighell AJ, Dietrich T, Nasser M, Rimal J, et al. A systematic review of medical interventions for oral submucous fibrosis and future research opportunities. Oral Dis. 2011;17(1 Suppl 1):42-57.

7. Van der Waal I. Historical perspective and nomenclature of potentially malignant or potentially premalignant oral epithelial lesions with emphasis on leukoplakia-some suggestions for modifications. Oral Surg Oral Med Oral Pathol Oral Radiol. 2018;125(6):577-81.

8. Kiran Kumar K, Saraswathi TR, Ranganathan K, Uma Devi M, Elizabeth J. Oral submucous fibrosis: a clinico-histopathological study in Chennai. Indian J Dent Res. 2007;18(3):106-11.

9. Pindborg JJ, Kalapesi ILK, Kale SA, Singh B, Taleyarkhan BN. Frequency of oral leukoplakia and related conditions among 10,000 Bombayites. Preliminary Rep, J Ind Dent Assoc. 1965;37:228-9.

10. Pindborg JJ, Chawla TN, Misra RK, Nagpaul RK, Gupta VK. Frequency of oral carcinoma, leukoplakia, leukokeratosis, leukoedema, sub mucous fibrosis and lichen planus in 10,000 Indians in Lucknow, Uttar Pradesh. India Preliminary J Dent Res. 1965;44(3):61.

11. Pindborg JJ, Bhat M, Devnath KR, Narayan HR, Ramchandra S. Frequency of oral white lesions in 10,000 individuals in Bangalore, South India, preliminary report. Ind J Med Sci. 1966;2:349-52.

12. Zachariah J, Mathew B, Varma NA, lqbal AM, Pindborg JJ. Frequency of oral mucosal lesions among 5000 individuals in Trivandrum, South India. Preliminary Rep J Indian Dent Assoc. 1966;38(11):290-4.

13. Pindborg JJ, Mehta FS, Gupta PC, Daftary DK. Prevalence of oral submucous fibrosis among 50,915 Indian villagers. Brit J Cancer. 1968;22:646-54.

14. Wahi PN, Mittal VP, Lahiri B, Luthera UK, Seth RK, Arma GD. Epidemiological study of precancerous lesions of the oral cavity: A preliminary report. Ind J Med Res. 1970;50:1361-91.

15. Mehta FS, Gupta PC, Daftary DK, Pindborg JJ, Choksi SK. An epidemiologic study of oral cancer and precancerous conditions among 101,761 villagers in Maharashtra. India Int J Cancer. 1972:10(1):134-41.

16. Lay KM, Sein K, Myint A, Ko SK, Pindborg JJ. Epidemiologic study of 600 villagers of oral precancerous lesions in Bilugyun: preliminary report. Community Dent Oral Epidemiol. 1982;10(3):152-5

17. Seedat HA, Vanwyk CW. Betelnut chewing and sub mucous fibrosis in Durban. South Africa Med J. 1988;74(3):568-71.

18. Tang JG, Jian XF, Gao ML, Ling TY, Zhang KH. Epidemiological survey of oral submucous fibrosis in Xiangtan City, Hunan Province. China Community Dent Oral Epidemiol. 1997:25(2):177-80.

19. Patil PB, Bathi $R$, Chaudhari S. Prevalence of oral mucosal lesions in dental patients with tobacco smoking, chewing, and mixed habits: a crosssectional study in South India. J Fam Community Med. 2013;20(2):130-5.

20. Hazarey VK, Erlewad DM, Mundhe KA, Ughade SN. Oral submucous fibrosis: study of 1000 cases from Central India. J Oral Pathol Med. 2007;36(1):12-7.

21. Mathew AL, Pai KM, Sholapurkar AA, Vengal M. The prevalence of oral mucosal lesions in patients visiting a dental school in southern India. Indian J Dent Res. 2008;19(2):99-103.

22. Mehrotra R, Pandya S, Chaudhary AK, Kumar M, Singh M. Prevalence of oral pre-malignant and malignant lesions at a tertiary level hospital in Allahabad. India Asian Pac J Cancer Prev. 2008;9(2):263-5.

23. Sharma R, Raj SS, Miahra G, Reddy YG, Shenava S, Narang P. Prevalence of oral submucous fibrosis in patients visiting dental college in rural area of Jaipur, Rajasthan. J Indian Acad Oral Med Radiol. 2012;24(1):1-4.

24. Agarwal A, Chandel S, Singh N, Singhal A. Use of tobacco and oral sub mucous fibrosis in teenagers. J Dent Sci Res. 3(3):1-4.

25. Bhatnagar $P$, Rai $S$, Bhatnagar G, Kaur M, Goel S, Prabhat M. Prevalence study of oral mucosal lesions, mucosal variants, and treatment required for patients reporting to a dental school in North India: in accordance with WHO guidelines. J Fam Community Med. 2013;20(1):41-8.

26. Burungale SU, Durge PM, Burungale DS, Zambare MB. Epidemiological study of premalignant and malignant lesions of the Oral cavity. J Acad Ind Res (JAIR). 2014:2(9):519-23.

27. Kumar NN, Aravinda K, Dhillon M, Gupta S, Reddy S, Srinivas RM. Prevalence of oral submucous fibrosis among habitual gutkha and areca nut chewers in Moradabad district. J Oral Biol Craniofac Res. 2014;4:8-13.

28. Patil S, Doni B, Maheshwari S. Prevalence and distribution of oral mucosal lesions in a geriatric Indian population. Can Geriatr J. 2015;18(1):11-4.

29. Singh P, Mittal R, Chandak S, Bhondey A, Rathi A, Chandwani M. Prevalence of oral submucous fibrosis in children of rural area of Nagpur, Maharashtra, India. Int J Prev Clin Dent Res. 2016:3(4):243-5.

30. Tyagi VN, More MD. Prevalence of Oral submucous fibrosis at OPD of ENT department of SMBT Institute of Medical Sciences, Nasik. J Appl Med Sci. 2018;6(1F):395-8.

31. Yang S, Wang Y, Su N, Yu H, Wei C, Yu C, Chang Y. Changes in prevalence of precancerous oral submucous fibrosis from 1996 to 2013 in Taiwan: a 
nationwide population-based retrospective study. J Formos Med Assoc. 2018;117(2):147-52.

32. More C, Rao NR, More S, Johnson NW. Reasons for initiation of areca nut and related products in patients with oral submucous fibrosis within an endemic area in Gujarat. India Subst Use Misuse. https://doi.org/10.1080/ 10826084.2019.1660678.

33. Cox SC, Walker DM. Oral submucous fibrosis. Rev Aust Dent J. 1996;41(5): 294-9.

34. More C, Peter R, Nishma G, Chen Y, Rao N. Association of Candida species with Oral submucous fibrosis and Oral leukoplakia: a case control study. Ann Clin Lab Res. 2018:06(3):248.

35. More C, Gupta S, Joshi J, Varma S. Classification system of Oral submucous fibrosis. J Indian Acad Oral Med Radiol. 2012;24(1):24-9.

36. More C, Shilu K, Gavli N, Rao NR. Etiopathogenesis and clinical manifestations of oral submucous fibrosis, a potentially malignant disorder: an update. Int J Curr Res. 2018;10(07):71816-20.

37. Gupta PC, Warnakulasuriya S. Global epidemiology of areca nut usage. Addict Biol. 2002;7(1):77-83.

38. Srinivasan M, Jewell SD. Evaluation of TGF-alpha and EGFR expression in oral leukoplakia and oral submucous fibrosis by quantitative immunohistochemistry. Oncol. 2001;61(4):284-92.

39. Anila Namboodiripad PC, Cystatin C. Cystatin C: its role in pathogenesis of OSMF. J Oral Biol Craniofac Res. 2014;4(1):42-6.

40. Hernandez BY, Zhu X, Goodman MT, Gatewood R, Mendiola P, Quinata K, et al. Betel nut chewing, oral premalignant lesions, and the oral microbiome. PLoS One. 2017;12(2):e0172196.

41. More CB, Gavli N, Chen Y, Rao NR. A novel clinical protocol for therapeutic intervention in oral submucous fibrosis: an evidence based approach. J Oral Maxillofac Pathol. 2018;22(3):382-91.

42. More C, Shah P, Rao N, Pawar R. Oral submucous fibrosis: an overview with evidence-based management. Int J Oral Health Sci Adv. 2015;3(3):40-9.

43. Pillai R, Balaram P, Reddiar KS. Pathogenesis of oral submucous fibrosis. Relationship to risk factors associated with oral cancer. Cancer. 1992;69(8): 2011-20.

44. Seedat HA, van Wyk CW. Submucous fibrosis in non-betel nut chewing subjects. J Biol Buccale. 1988;16(1):3-6.

45. Rajalalitha P, Vali S. Molecular pathogenesis of oral submucous fibrosis-a collagen metabolic disorder. J Oral Pathol Med. 2005:34(6):321-8.

46. Chaturvedi P, Vaishampayan SS, Nair S, Nair D, Agarwal JP, Kane SV, et al. Oral squamous cell carcinoma arising in background of oral submucous fibrosis: a clinicopathologically distinct disease. Head Neck. 2013;35(10): 1404-9.

47. More C, Pawar R, Rao N, Shah P, Gavli N. Oral ulcer: an overview with an emphasis on differential diagnosis. Int J Oral Health Sci Adv. 2015;3(4):1-13.

48. Dyavanagoudar SN. Oral submucous fibrosis: review on etiopathogenesis. $J$ Cancer Sci Ther. 2009; 1 (2):72-7.

49. Lee CK, Tsai MT, Lee HC, Chen HM, Chiang CP, Wang YM, et al. Diagnosis of oral submucous fibrosis with optical coherence tomography. J Biomed Opt. 2009;14(5):054008.

50. Tadakamadla J, Kumar S, Lalloo R, Gandhi Babu DB, Johnson NW. Impact of oral potentially malignant disorders on quality of life. J Oral Pathol Med. 2018:47(1):60-5.

51. Hebbar PB, Sheshaprasad R, Gurudath S, Pai A, Sujatha D. Oral submucous fibrosis in India: are we progressing?? Indian J Cancer. 2014;51(3):222-6.

52. Passi $D$, Bhanot $P$, Kacker $D$, Chahal $D$, Atri M, Panwar $Y$. Oral submucous fibrosis: newer proposed classification with critical updates in pathogenesis and management strategies. Natl J Maxillofac Surg. 2017;8(2):89.

53. Arakeri G, Brennan PA. TFM classification and staging of oral submucous fibrosis: A new proposal. J Oral Pathol Med. 2018;47(5):539.

54. Gnanam A. Kannadasan Kamal, Venkatachalapathy S, David Jasline. Multimodal treatment options for oral submucous fibrosis, SRM University. J Dent Sci. 2010;1(1):26-9.

55. Karemore TV, Motwani M. Evaluation of the effect of newer antioxidant lycopene in the treatment of oral submucous fibrosis. Indian J Dent Res. 2012;23(4):524-8.

56. Hazarey VK, Sakrikar AR, Ganvir SM. Efficacy of curcumin in the treatment for oral submucous fibrosis - a randomized clinical trial. J Oral Maxillofac Pathol. 2015;19(2):145-52.

57. Maher R, Aga P, Johnson NW, Sankaranarayanan R, Warnakulasuriya S. Evaluation of multiple micronutrient supplementation in the management of oral submucous fibrosis in Karachi. Pakistan Nutr Cancer. 1997;27(1):41-7.
58. Patil S, Al-Zarea BK, Maheshwari S, Sahu R. Comparative evaluation of natural antioxidants spirulina and aloe vera for the treatment of oral submucous fibrosis. J Oral Biol Craniofac Res. 2015;5(1):11-5.

59. Alam S, Ali I, Giri KY, Gokkulakrishnan S, Natu SS, Faisal M, et al. Efficacy of aloe vera gel as an adjuvant treatment of oral submucous fibrosis. Oral Surg Oral Med Oral Pathol Oral Radiol. 2013;116(6):717-24.

60. Goel S, Ahmed J. A comparative study on efficacy of different treatment modalities of oral submucous fibrosis evaluated by clinical staging in population of southern Rajasthan. J Cancer Res Ther. 2015;11(1):113-8.

61. James L, Shetty A, Rishi D, Abraham M. Management of oral submucous fibrosis with injection of hyaluronidase and dexamethasone in grade III oral submucous fibrosis. J Int Oral Health. 2015 Aug;7(8):82-5.

62. Krishnamoorthy B, Khan M. Management of oral submucous fibrosis by two different drug regimens: a comparative study. Dent Res J (Isfahan). 2013; 10(4):527-32.

63. Singh P, Pandey A, Shingh A, Ahuja T, Sharma S, Bhagalia S, Trehan M. Efficacy of intralesional placental extract, dexamethasone and hyaluronidase in treatment of oral submucous fibrosis: a comparative study. JK Pract. 2016; 21(1-2):29-34

64. Bhadage CJ, Umarji HR, Shah K, Välimaa H. Vasodilator isoxsuprine alleviates symptoms of oral submucous fibrosis. Clin Oral Investig. 2013;17(5):1375-82

65. Rajendran R, Rani V, Shaikh S. Pentoxifylline therapy: a new adjunct in the treatment of oral submucous fibrosis. Indian J Dent Res. 2006;17(4):190-8.

66. Vijayakumar M, Priya D. Physiotherapy for improving mouth opening \& tongue protrusion in patients with Oral submucous fibrosis (OSMF) - case series. Int J Pharm Sci Health Care. 2013;3(2):50-8.

67. Kamath W. Surgical interventions in Oral submucous fibrosis: a systematic analysis of the literature. J Maxillofac Oral Surg. 2015;14(3):521-31.

68. Koneru A, Hunasgi S, Hallikeri K, Surekha R, Nellithady GS. Vanishree M. Treat Modalities OSMF J Adv Clin Res Insights. 2014;1(2):64-72.

69. Arakeri G, Rai KK, Boraks G, Patil SG, Aljabab AS, Merkx MA, et al. Current protocols in the management of oral submucous fibrosis: an update. J Oral Pathol Med. 2017;46(6):418-23.

70. Warnakulasuriya S, Kerr AR. Oral submucous fibrosis: a review of the current management and possible directions for novel therapies. Oral Surg Oral Med Oral Pathol Oral Radiol. 2016:122(2):232-41.

71. Heck JE, Marcotte EL, Argos M, Parvez F, Ahmed A, Islam T, et al. Betel quid chewing in rural Bangladesh: prevalence, predictors and relationship to blood pressure. Int J Epidemiol. 2012 Apr;41(2):462-71.

72. Aziz SR. Oral submucous fibrosis: case report and review of diagnosis and treatment. J Oral Maxillofac Surg. 2008;66(11):2386-9.

73. Murti P, Bhonsle R, Pindborg JJ, Daftary D, Gupta P, Mehta FS. Malignant transformation rate in oral submucous fibrosis over a 17 -year period. Community Dent Oral Epidemiol. 1985;13(6):340-1.

74. Paymaster JC. Cancer of the buccal mucosa; a clinical study of 650 cases in Indian patients. Cancer. 1956 May;9(3):431-5.

75. Hsue SS, Wang WC, Chen CH, Lin CC, Chen YK, Lin LM. Malignant transformation in 1458 patients with potentially malignant oral mucosal disorders: a follow-up study based in a Taiwanese hospital. J Oral Pathol Med. 2007;36(1):25-9.

76. Arakeri G, Patil SG, Aljabab AS, Lin KC, Merkx MA, Gao S, et al. Oral submucous fibrosis: an update on pathophysiology of malignant transformation. J Oral Pathol Med. 2017:46(6):413-7.

77. Ray JG, Ranganathan K, Chattopadhyay A. Malignant transformation of oral submucous fibrosis: overview of histopathological aspects. Oral Surg Oral Med Oral Pathol Oral Radiol. 2016;122(2):200-9.

78. Guo F, Jian XC, Zhou SH, Li N, Hu YJ, Tang ZG. A retrospective study of oral squamous cell carcinomas originated from oral submucous fibrosis. Zhonghua Kou Qiang Yi Xue Za Zhi. 2011;46(8):494-7.

79. Shah JP, Batsakis JG, Johnson NW. Oral cancer. London: Dunitz; 2003.

80. Shah JP, Johnson NW. Oral and oropharyngeal cancer. Boca Raton, FL: CRC Press; 2018.

81. Bazarsad S, Zhang X, Kim K-Y, Illeperuma R, Jayasinghe RD, Tilakaratne WM, et al. Identification of a combined biomarker for malignant transformation in oral submucous fibrosis. J Oral Pathol Med. 2016;46(6):431-8.

82. Mckay AJ, Patel RKK, Majeed A. Strategies for Tobacco Control in India: A Systematic Review. Plos One. 2015;10(4).

83. Arora M, Tewari A, Tripathy V, Nazar GP, Juneja NS, Ramakrishnan L, et al. Community-based model for preventing tobacco use among disadvantaged adolescents in urban slums of India. Health Promot Int. 2010; 25:143-52. 
84. Kumar MS, Sarma PS, Thankappan KR. Community-based group intervention for tobacco cessation in rural Tamil Nadu, India: a cluster randomized trial. J Subst Abus Treat. 2012:43:53-60.

85. Prabhu RV. A need to spread awareness regarding the ill effects of Arecanut and its commercial products on Oral health. Tropical Medicine \& Surgery. 2014;02(03). Garg a, Chaturvedi P, Gupta PC. A review of the systemic adverse effects of areca nut or betel nut. Indian J Med Paediatr Oncol. 2014; 35(1):3-9.

86. Arora M, Madhu R. Banning smokeless tobacco in India: policy analysis. Indian J Cancer. 2012;49(4):336.

87. Garg A, Chaturvedi P, Gupta PC. A review of the systemic adverse effects of areca nut or betel nut. Indian J Med Paediatr Oncol. 2014;35(1):3-9.

88. Chakrabarti S, Mishra A, Agarwal JP, Garg A, Nair D, Chaturvedi P. Acute toxicities of adjuvant treatment in patients of oral squamous cell carcinoma with and without submucous fibrosis: a retrospective audit. J Cancer Res Ther. 2016;12(2):932-7.

\section{Publisher's Note}

Springer Nature remains neutral with regard to jurisdictional claims in published maps and institutional affiliations.

Ready to submit your research? Choose BMC and benefit from:

- fast, convenient online submission

- thorough peer review by experienced researchers in your field

- rapid publication on acceptance

- support for research data, including large and complex data types

- gold Open Access which fosters wider collaboration and increased citations

- maximum visibility for your research: over $100 \mathrm{M}$ website views per year

At $\mathrm{BMC}$, research is always in progress.

Learn more biomedcentral.com/submissions 